\title{
Modularity in receptor evolution: insulin- and glucagon-like peptide modules as binding sites for insulin and glucose in the insulin receptor
}

\author{
This article was published in the following Dove Press journal: \\ Journal or Receptor, Ligand and Channel Research \\ 24 July 2010 \\ Number of times this article has been viewed
}

\author{
Robert Root-Bernstein' \\ Jessica Vonck ${ }^{2}$ \\ 'Department of Physiology, Michigan \\ State University, Missouri, USA; \\ ${ }^{2}$ College of Human Medicine, Michigan \\ State University, Missouri, USA
}

\begin{abstract}
Dwyer suggested that peptide receptors evolved from self-aggregating peptides. Root-Bernstein extended Dwyer's theory to include complementary molecules. Insulin is a self-aggregating peptide. Insulin is also complementary (and therefore binds) to glucagon. We have shown previously using similarities searches that the insulin receptor (IR) has several insulin-like and several glucagon-like sequences associated with insulin-binding regions. We demonstrate here that peptides derived from these insulin- and glucagon-like regions bind insulin with up to high-nanomolar affinity, providing experimental evidence for the evolution of the IR from insulin- and glucagon-like modules. Moreover, we demonstrate that insulin itself binds glucose (and cytochalasin B), and that many of the insulin-like regions of the IR (but not the glucagon-like regions of the insulin receptor) do likewise. These data suggest the function of insulin, and of the IR in glucose regulation has been directed by chemical selection for their mutual set of molecular interactions. This model may be generalizable to the evolution of other receptor and transporter systems. The relationship between molecular structure and function within living systems may be highly constrained by selection for molecular complementarity.
\end{abstract}

Keywords: co-evolution, modular evolution, molecular complementarity, chemical selection, molecular paleontology

\section{Introduction}

\section{Basic theoretical questions and proposals}

How did receptors evolve in early biotic systems? The problem often presents itself as a chicken-and-egg situation. Which came first: the ligand or the receptor? How can a ligand evolve and be selected for in the absence of its receptor, or a receptor evolve in the absence of its ligand? If ligand and receptor must co-evolve, what principles determine such co-evolution?

Surprisingly little research has been devoted to this question. ${ }^{1-5}$ In the absence of any understanding of the selection pressures that shaped receptor evolution, it is consequently difficult to address the mechanistic and functional aspects of their structures, or to relate structure to function. We present here evidence that there is a very basic, conceptually simple set of principles relating to the evolution, structure, and function of the insulin receptor that may be more widely generalizable. Because there appears to be a "molecular paleontology" embedded within the modern insulin receptor that reflects its past evolution, the results also have very practical biochemical and clinical implications.

Unveiling the processes by which evolution produced the complex machinery associated with cellular function is an important and nontrivial task for life scientists.
Correspondence: Robert Root-Bernstein Department of Physiology, 2174 Biomedical and Physical Sciences Building, Michigan State University, East Lansing, MI 48824 USA Email rootbern@msu.edu 
The origins of receptors present a particularly thorny problem since it is difficult to imagine how complex receptor-secondmessenger systems could have evolved by gradual steps. Dwyer ${ }^{3,4}$ has provided a key insight into such a step-wise process by proposing that some peptide receptors may have evolved from the self-aggregating peptides. During evolution, the exons encoding such self-aggregating peptides could have been duplicated and spliced to exons encoding conserved transmembrane spanning modules and enzymatic modules (or other transducers), resulting in primitive receptors that variation and selection could have modified and elaborated. ${ }^{1,2}$ Many peptide receptors do appear to have ligand-like regions in their binding sites, including the LFA-3 protein and CD2 protein; immunoglobulins (which share homologies with the Fc receptor); bungarotoxin (an acetylcholine receptor antagonist that mimics the acetylcholine receptor binding site); alpha scorpion toxins (which mimic the sodium channel proteins they block); interleukin 1 and interleukin 2; transforming growth factor-beta; thionin and crambin (plant defense molecules); neurophysin; and interleukin $1 .^{3-6}$ Insulin, glucagon, and gastrin are also self-aggregating peptides that have multiple sequence homologies with regions of their receptors that are associated with ligand binding. ${ }^{1,2}$

Root-Bernstein ${ }^{1,2}$ has suggested that, in addition to selfaggregation (or homo-complementarity), receptor evolution may also involve complementarity between different molecules (hetero-complementarity). For example, insulin and glucagon are molecularly complementary, binding to each other with mid-micromolar affinity. ${ }^{7,8}$ Notably, the insulin receptor has multiple glucagon-like regions, while the glucagon receptor has multiple insulin-like regions. ${ }^{1,2}$ These hetero-complementary regions are, like the homo-complementary regions described above, also associated with ligand binding. ${ }^{1,2}$ Thus, both homocomplementarity and hetero-complementarity could have played roles in the evolution of receptors.

Molecular complementarity may also provide selection pressures that resulted not only in the selection of ligands for their particular structures, but also for their particular functions. ${ }^{9}$ Why, for example, does insulin, rather than some other peptide sequence, regulate glucose uptake by cells? Molecular complementarity suggests the possibility that insulin was selected by evolution to modulate glucose activity because glucose binds directly to insulin. Insulin is known to have two high affinity (ca. $1 \times 10^{-3} \mathrm{M}$ ) and four low affinity (ca. $6 \times 10^{-2} \mathrm{M}$ ) binding sites for glucose. ${ }^{9-13}$ We therefore hypothesized, and demonstrated, in a previous publication that the insulin-like sequences of the insulin receptor may also bind glucose. ${ }^{14}$ Because these potential glucose-binding regions are also associated with insulin binding, insulin binding to its receptor is glucose sensitive. ${ }^{14}$ So it is possible that glucose, insulin, and the insulin receptor each play the roles they play in metabolism because they were selected for their mutual set of chemical interactions. These direct chemical interactions may have been the primitive biological control systems from which the complex second-messenger systems evolved that govern metabolism today.

As noted above, we have previously demonstrated that glucose binds to the IR modifying insulin binding to it. ${ }^{14}$ We report here experiments further characterizing insulin receptor specificity for insulin and for glucose, in light of our evolution-based hypotheses. In particular, we more than double the number of tests of insulin and glucose binding to insulin-receptor peptides in comparison with our previous publication on this topic; ${ }^{14}$ demonstrate that insulin and glucose binding does not occur with ascorbate-binding peptides $^{15}$ derived from the $\mathrm{H} 1$ histamine receptor (H1HR) or the beta 2 adrenergic receptor (B2AR); and place all of the data for the first time in the context of how the insulin and other small-molecule receptors may have co-evolved.

\section{Materials and methods Glucose binding to insulin and insulin receptor peptides}

Initial experiments were designed to determine binding of glucose and cytochalasin B to insulin (bovine insulin, Sigma-Aldrich Chemical Co.) and individual peptides derived from the insulin receptor. Peptide regions previously identified as being either insulin-like (IL) or glucagon-like (GL) regions of the IR (see Table 1), ${ }^{1,2}$ and peptides associated with ascorbate binding to the beta-2 adrenergic (B2AR) or H1 histamine (H1HR) receptors, ${ }^{15}$ were synthesized by the Mass Spectrometry, Synthesis and Sequencing Facility of the Department of Biochemistry at Michigan State University, and purified to $>99 \%$ purity as determined by HPLC. Insulin $(2.5 \mathrm{mg} / \mathrm{ml})$ and IR peptides $(1.0 \mathrm{mg} / \mathrm{mL})$ were dissolved as solutions of ca. $0.5 \mathrm{mM}$ in $\mathrm{pH} 7.4$ phosphate buffer (Fisher Scientific). A 1.0 M D-glucose (Sigma-Aldrich) was made as a stock solution in the same buffer and diluted by thirds. $100 \mu \mathrm{L}$ of each glucose concentration plus $100 \mu \mathrm{L}$ of buffer, and mixtures of $100 \mathrm{ul}$ of each peptide with $100 \mu \mathrm{L}$ of buffer or with $100 \mu \mathrm{L}$ of each glucose concentration were made in a crystal 96-well plate and a complete spectrum of each well recorded on a Spectromax Plus spectrophotometer. Data were collected using SoftMax Pro 4.0 software. Every combination was done in triplicate and the results averaged. 
Table I Summary of experiments carried out on horse radish peroxidase-linked insulin (Ins-HRP) using an ELISA-like methodology, human recombinant insulin (Humulin ${ }^{\circledR}$, Lilly) measured free in solution using UV spectroscopy, glucose (UV spectroscopy) or cytochalasin B (cyto B) (UV spectroscopy) binding to insulin, glucagon, peptides derived from the insulin receptor (IR), ${ }^{1,2}$ peptides derived from the $\mathrm{HI}$ histamine receptor (HIHR), ${ }^{15}$ and peptides derived from the beta 2 adrenergic receptor (B2AR) ${ }^{15}$

\begin{tabular}{|c|c|c|c|c|}
\hline $\begin{array}{l}\text { Kd for binding between receptor } \\
\text { peptides, insulins, and glucose }\end{array}$ & Ins-HRP & Humulin & Glucose & Cyto B \\
\hline Insulin & & & $250 \mu \mathrm{M}$ and $30 \mathrm{mM}$ & $13 \mu \mathrm{M}$ \\
\hline Glucagon & $150 \mathrm{nM}$ & $89 \mu \mathrm{M}$ & $>100 \mathrm{mM}$ & nd \\
\hline \multicolumn{5}{|l|}{ Insulin receptor peptides } \\
\hline 9I-I03 (IL) FRVYGLESLKDLF & $70 \mathrm{nM}$ & $5 \mu \mathbf{M}$ & $37 \mathrm{mM}$ & nd \\
\hline 95-II3 (IL) GLESLKDLFPNLTVIRGSR & $21 \mathrm{nM}$ & $2 \mu \mathrm{M}$ & II mM & $75 \mu \mathrm{M}$ \\
\hline I05-II8 (IL) NLTV I RGSRLFFNY & $1.8 \mathrm{nM}$ & $2 \mu \mathrm{M}$ & $35 \mathrm{mM}$ & nd \\
\hline I57-I66 (GL) T I DWSRILDS & $30 \mathrm{nM}$ & 150 uM & $57 \mathrm{mM}$ & $112 \mu \mathrm{M}$ \\
\hline 223-234 (ns) CKSHGCTAEGLC & $>I \mu \mathrm{M}$ & $>I \mathrm{mM}$ & $>100 \mathrm{mM}$ & nd \\
\hline 233-248 (IL) CCHSECLGNCSQPDD & $8.0 \mathrm{nM}$ & $44 \mu \mathrm{M}$ & $3 \mathrm{mM}$ & nd \\
\hline 284-300 (GL) SFCQDLHHKCKNSRR QG & $8.5 \mathrm{nM}$ & $46 \mu \mathrm{M}$ & $>100 \mathrm{mM}$ & $\mathrm{I} \mathrm{mM}$ \\
\hline 390-405 (GL) E ISGYLKIRRSYALVS & $150 \mathrm{nM}$ & $330 \mu \mathrm{M}$ & $30 \mathrm{mM}$ & $166 \mu \mathrm{M}$ \\
\hline 392-404(GL) SGYLKIRRSYALV & $300 \mathrm{nM}$ & $82 \mu \mathrm{M}$ & $54 \mathrm{mM}$ & $180 \mu \mathrm{M}$ \\
\hline 424-444 (GL) YSFYALDNQNLRQLWDWSKH & $>I \mu \mathrm{M}$ & $400 \mu \mathrm{M}$ & $>100 \mathrm{mM}$ & $>1 \mathrm{mM}$ \\
\hline 453-464 (IL) TQGKLFFHYNPK & $7.6 \mathrm{nM}$ & $45 \mu \mathrm{M}$ & $57 \mathrm{mM}$ & nd \\
\hline 660-679 (IL) ERQAEDSELFELDYCLKGLK & $370 \mathrm{nM}$ & $>1 \mathrm{mM}$ & $70 \mathrm{mM}$ & $117 \mu \mathrm{M}$ \\
\hline 897-916 (IL) LCVSRKHFALERGCRLRGL & $1.5 \mathrm{nM}$ & $6.2 \mu \mathrm{M}$ & $14 \mathrm{mM}$ & $25 \mu \mathrm{M}$ \\
\hline \multicolumn{5}{|l|}{ Histamine $\mathrm{HI}$ receptor peptides } \\
\hline HIHR 77-87 GAVVNMNILY & nd & $>1 \mathrm{mM}$ & $60 \mathrm{mM}$ & nd \\
\hline HIHR I05-II5 SMDYVASTASI & $>I \mu M$ & $>I \mathrm{mM}$ & $>100 \mathrm{mM}$ & nd \\
\hline \multicolumn{5}{|l|}{ Beta 2 adrenergic receptor peptides } \\
\hline B2AR 97-I06 KMWTFGNFWC & $>I \mu M$ & $>I \mathrm{mM}$ & $60 \mathrm{mM}$ & nd \\
\hline B2AR I03-II3 FWCEFWTSIDV & nd & $>I \mathrm{mM}$ & $75 \mathrm{mM}$ & nd \\
\hline B2AR I75-I88 RATHQEAINCYANE & nd & $>\mathrm{I} \mathrm{mM}$ & $65 \mathrm{mM}$ & nd \\
\hline
\end{tabular}

Notes: Peptides from the IR are labeled as being insulin-like (IL) or glucagon-like (GL) or, have no significant similarity (ns) to either insulin or glucagon. I,2 Combinations that were not investigated are indicated with "nd", meaning "not done." The lowest binding constants (Kd) are indicated by bolded figures and coincide almost completely with insulin-like (IL) peptides derived from the IR. Note that insulin binds best to insulin-like modules from the IR, and that there is also insulin binding to some glucagon-like modules as well. Insignificant binding was observed to peptides derived from receptors other than the IR. Binding of insulin-HRP to IR peptides (ELISA-like method) is about 200 to 1000 times stronger than Humulin binding (UV spectroscopy), as a result of decreasing the thermodynamic degrees of freedom when constraining the IR peptides to an ELISA plate (see text for interpretation of results). Glucose binding is limited almost exclusively to insulin-like modules derived from the IR. Glucose does not have significant affinity for glucagon or glucagon-like modules of the IR or peptides derived from other receptors. Cytochalsin B binding is stronger than glucose binding to the peptides, but follows exactly the same pattern, as would be expected for a glucose antagonist. About a third of these data appeared in a previous publication. 44 See Table 2 for a schematic diagram of where the various insulin-like and glucagon-like modules are located on the IR.

These curves were examined for the absorbance at which the greatest spectral shifts occurred (usually between 195 and $205 \mathrm{~nm}$ ) and these data analyzed to produce binding constants (Kd) determined by the difference in absorbance between the absorbance obtained from the mixture of the peptide with glucose and the sums of the peptides (plus buffer) and glucose (plus buffer) individually.

\section{Cytochalasin B binding to insulin and insulin receptor peptides}

Following a procedure described by us previously for measuring binding to receptors, ${ }^{15} \mathrm{UV}$ spectrophotometry was also used to measure cytochalasin B (Sigma-Aldrich) binding to insulin and to the IR peptides, but a different protocol was followed since the cytochalasin B is not soluble in the buffer, and was supplied in pure DMSO. $10 \mathrm{mM}$ cytochalasin B (DMSO) was serially diluted by thirds with phosphate buffer to produce eight dilutions. DMSO was similarly diluted to make solutions with matching DMSO concentrations. The same peptide solutions as above were utilized. $200 \mu \mathrm{L}$ of a peptide in phosphate buffer was put in two wells of a crystal 96 well plate, and phosphate buffer alone in another two. $20 \mu \mathrm{L}$ of the lowest concentration of cytochalasin B solution was added to one peptide well and one buffer well, and $20 \mu \mathrm{L}$ of the lowest concentration of DMSO solution was added to the other peptide and buffer wells. The spectra of the wells was collected from 190 to $240 \mathrm{~nm}$ and saved. The process was repeated by adding the next higher concentration of cytochalasin B and DMSO, etc. until the highest concentration was added and the spectra recorded. In order to determine 
whether cytochalasin B bound to the peptide, the buffer plus DMSO dilutions data were subtracted from all corresponding spectra; then the spectra for the peptide and cytochalasin B wells were added to provide expected values and this was compared with the actual values obtained from the mixing of peptide and cytochalasin B. The clearest binding curves were found in the range of $200-210 \mathrm{~nm}$.

\section{Humulin ${ }^{\circledR}$ binding to peptides derived from the insulin receptor}

Insulin receptor peptides, $1 \mathrm{mg}$ per $1 \mathrm{~mL}$, and serial dilutions by thirds were used with UV spectroscopy of each peptide against recombinant human insulin (Humulin ${ }^{\circledR}$ ). Humulin $\mathrm{R}$ from Lilly was diluted to a constant concentration of $1 \mathrm{uL}$ per $1 \mathrm{~mL}$ to make a stock solution. $100 \mathrm{ul}$ of each peptide concentration was added to three wells of a crystal 96 well plate, and $100 \mathrm{uL}$ of $\mathrm{pH} 7.4$ phosphate buffer (Fisher Scientific) added to each. $100 \mathrm{ul}$ of buffer were also added to three wells of $100 \mathrm{uL}$ Humulin R stock solution. $100 \mathrm{ul}$ of Humulin R stock solution were added to three wells of each dilution of the insulin receptor peptide. Finally, three wells were filled with $200 \mathrm{uL}$ of buffer solution. Solutions were incubated at room temperature for 30 minutes to maximize binding before being read from 190 to $300 \mathrm{~nm}$ in a SPECTRAmax Plus spectrophotometer. Data were collected using software. Binding constants were calculated using an Excel program. The buffer reading at each absorbance was subtracted from the absorbances of all other wells. The remaining absorbances for the peptide concentrations was added to the remaining absorbance of the Humulin R to give an expected absorbance. The difference of the expected absorbance and the actual experimental absorbance of the peptide-Humulin combination was then determined and these differences plotted according to peptide concentration. The best binding curves were visible between 190 and $200 \mathrm{~nm}$.

\section{Insulin-HRP binding to peptides derived from the insulin receptor}

A modified version of enzyme-linked adsorption assay (ELSA) was used to measure insulin binding to the peptides derived from the insulin receptor. ${ }^{7,14} 0.5 \mathrm{mg}$ of insulin-HRP (insulin conjugated to horse radish peroxidase [Sigma-Aldrich]) was diluted in $2.0 \mathrm{~mL}$ of $\mathrm{pH} 7.4$ phosphate buffer as a stock solution $(5 \mu \mathrm{M})$. Serial dilutions of the insulin-HRP were then made from 1:100 to $1: 333,333$ by thirds, producing solutions that varied in insulin-HRP concentration from $50 \mathrm{nM}$ to $15 \mathrm{pM}$. Each insulin receptor peptide was dissolved in buffer to produce a $50 \mu \mathrm{M}$ stock solution and $100 \mu \mathrm{L}$ were then added to an ELISA plate (Costar), incubated for an hour, and then triply washed with a $1 \%$ solution of TWEEN in phosphate buffer. $200 \mu \mathrm{L}$ of a $2 \%$ polyvinylalcohol (PVA) blocking agent in phosphate buffer was added to each well, incubated for an hour, and triply washed. $100 \mu \mathrm{L}$ of each dilution of the insulin-HRP solution was then added to a well, incubated for an hour, and triply washed. Finally, $100 \mu \mathrm{L}$ of ABTS single reagent (Chemicon, Temecula, CA, USA) was added to each well, incubated for 30 minutes, and the plate read at $405 \mathrm{~nm}$. All combinations and controls were run in duplicate and the resulting values averaged.

\section{Data analysis}

All data were analyzed and plotted using an Excel spreadsheet program.

\section{Note on insulin receptor numbering}

All IR sequences are provided in the SwissProt numbering system (http://www.expasy.ch) that begins with the pre-pro sequence. Many papers on the IR use a numbering system that begins with the edited transcript (eg, refs. 26 and 31) and thus have 27 amino acids subtracted from the number as compared with the SwissProt convention.

\section{Results}

Table 1 summarizes the results of all of the experiments carried out involving insulin binding to IR, H1HR and B2AR peptides; glucose binding to IR, H1HR, and B2AR peptides; and cytochalasin $\mathrm{B}$ binding to IR peptides. We began by validating the use of UV spectrometry for this study by demonstrating that we could reproduce the phenomenon of glucose binding to insulin. Figure 1 shows that we were able to visualize the two-step binding curve that one would expect from previous reports which imply that insulin contains both high affinity (ca. $1 \times 10^{-3} \mathrm{M}$ ), and low affinity (ca. $6 \times 10^{-2} \mathrm{M}$ ), binding sites for glucose..$^{10-13}$ We found slightly lower binding constants of $250 \mathrm{uM}$ and $30 \mathrm{mM}$ (Table 1), which may simply reflect differences in the buffers employed by various investigators. We also confirmed that cytochalasin B, a potent glucose transport antagonist, binds to insulin with an even lower binding constant of $13 \mu \mathrm{M}$ (Figure 2). No measurable binding was found between glucose and glucagon (data not shown).

Figure 3 illustrates some of the data obtained from binding experiments between insulin-HRP and IR peptides. Binding constants were determined from the inflection points of the curves, and varied between $1.5 \mathrm{nM}$ and greater than $1 \mathrm{mM}$ (ie, effectively unmeasurable by this technique). The binding constants using both the insulin-HRP "ELSA" and 


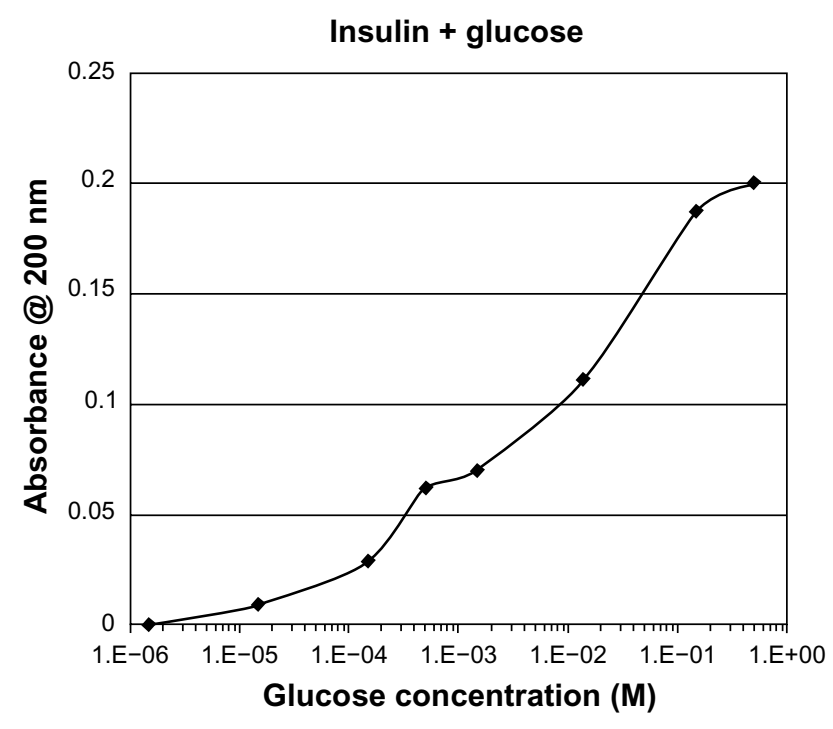

Figure I UV spectroscopic study of glucose binding to insulin showing clearly that there are both high affinity $\left(\mathrm{ca} .1 \times 10^{-3} \mathrm{M}\right)$ and low affinity $\left(\mathrm{ca} .6 \times 10^{-2} \mathrm{M}\right)$ binding sites. The binding constants were determined from the inflection points of the curves. The same technique was used to determine glucose binding to IR peptides (Table I).

Humulin-R-UV-spectroscopy methods are summarized in Table 1. Binding constants determined by UV spectroscopy were uniformly 200 to 1000 times higher than by insulinHRP "ELSA", but were extremely consistent with whether there was measurable binding or not. These data show that insulin binds to insulin-like modules of the IR, and to some glucagon-like modules, but does not bind significantly to a peptide that mimics neither insulin nor glucagon, nor to peptides derived from the beta- 2 adrenergic receptor (B2AR) or the histamine receptor (H1HR).

Table 1 goes on to demonstrate that glucose and cytochalasin B bind to many, but not all, insulin-like regions of the IR, with affinities similar to those for their binding to insulin itself. Glucose and cytochalasin B do not, however, bind

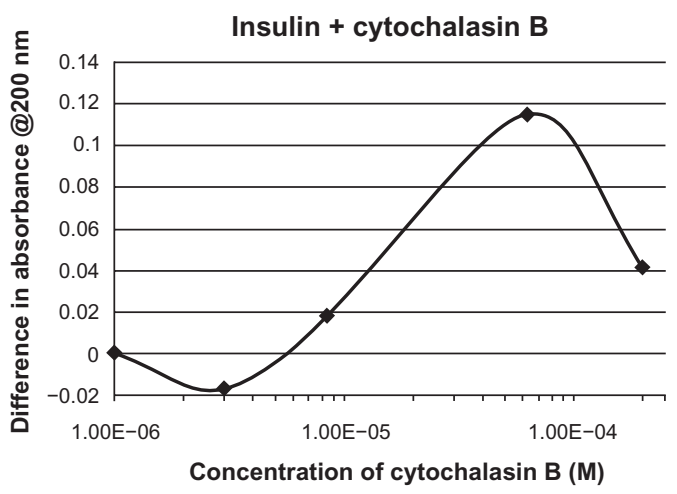

Figure 2 Cytochalasin B binds to insulin with a binding constant of ca. $13 \mu \mathrm{M}$, confirming the existence of at least one high affinity glucose binding site. The binding constant was determined from the inflection point of the curve. Similar results were obtained for binding of cyto B to IR peptides that were found to bind glucose (Table I). ${ }^{14}$ significantly to glucagon or to glucagon-like regions of the IR $(\mathrm{Kd}>100 \mathrm{mM})$, nor to an IR peptide that mimics neither insulin or glucagon. No physiologically significant binding of glucose to H1HR or B2AR was observed.

Table 1 also demonstrates that insulin itself binds to both insulin-like and glucagon-like peptide regions of the IR. Binding of insulin-HRP is in the nanomolar range, but binding of unlabelled recombinant human insulin (Humulin) was generally between 100 and 1000 times less. No significant binding of insulin to H1HR or B2AR receptor peptides was found. Figure 3 illustrates some of the insulin-HRP binding data.

Table 2 plots the insulin-like and glucagon-like regions of the IR on the SwissProt (ID\# P06213) sequence. Table 2 also shows where antibody interference studies, alanine-scanning mutagenesis studies, and mutations associated with impaired insulin binding (especially Leprechaunism) map onto this sequence. The table demonstrates that all of the extracellular insulin-like peptides map to regions that are known to be involved in insulin binding with one exception, which is the 897-917 peptide from the receptor B chain. The highest affinity glucose binding sites are localized to the same regions. On the other hand, Table 2 also illustrates the fact that insulin binding to the IR also involves a number of regions not associated with insulin- or glucagon-like modules.

\section{Discussion}

The insulin receptor has multiple high and low affinity sites that interact in both positively and negatively cooperative manners, making insulin binding very complex..$^{16}$ The insulin-HRP ELSA-like experiments yielded binding constants (1.5 to $8.5 \mathrm{nM}$ ) that are about eight- to thirty-fold lower than those found for the high-affinity binding of native insulin to the native IR (ca. $250 \mathrm{pM}$ ). ${ }^{18,19}$ The difference between insulin binding to native IR and the peptides in our study is hardly surprising, since ligand binding to receptors is usually mediated by the tertiary or quaternary structure of the receptor, which is lacking in the peptides. Our data may therefore suggest that the peptide modules we have characterized may cooperate through tertiary conformational effects to create higher affinity insulin binding sites in the native IR, or they may represent some of the lower affinity insulin binding sites (ca. $1 \mathrm{nM})^{16}$ that are known to exist on the IR. In either case, it is likely that the insulin-like and glucagon-like modules characterized here play some role in insulin binding to the IR.

Our data also demonstrate that while insulin binds to insulin-like and glucagon-like modules on the IR, binding 


\section{Insulin-HRP Binding to insulin receptor peptides}

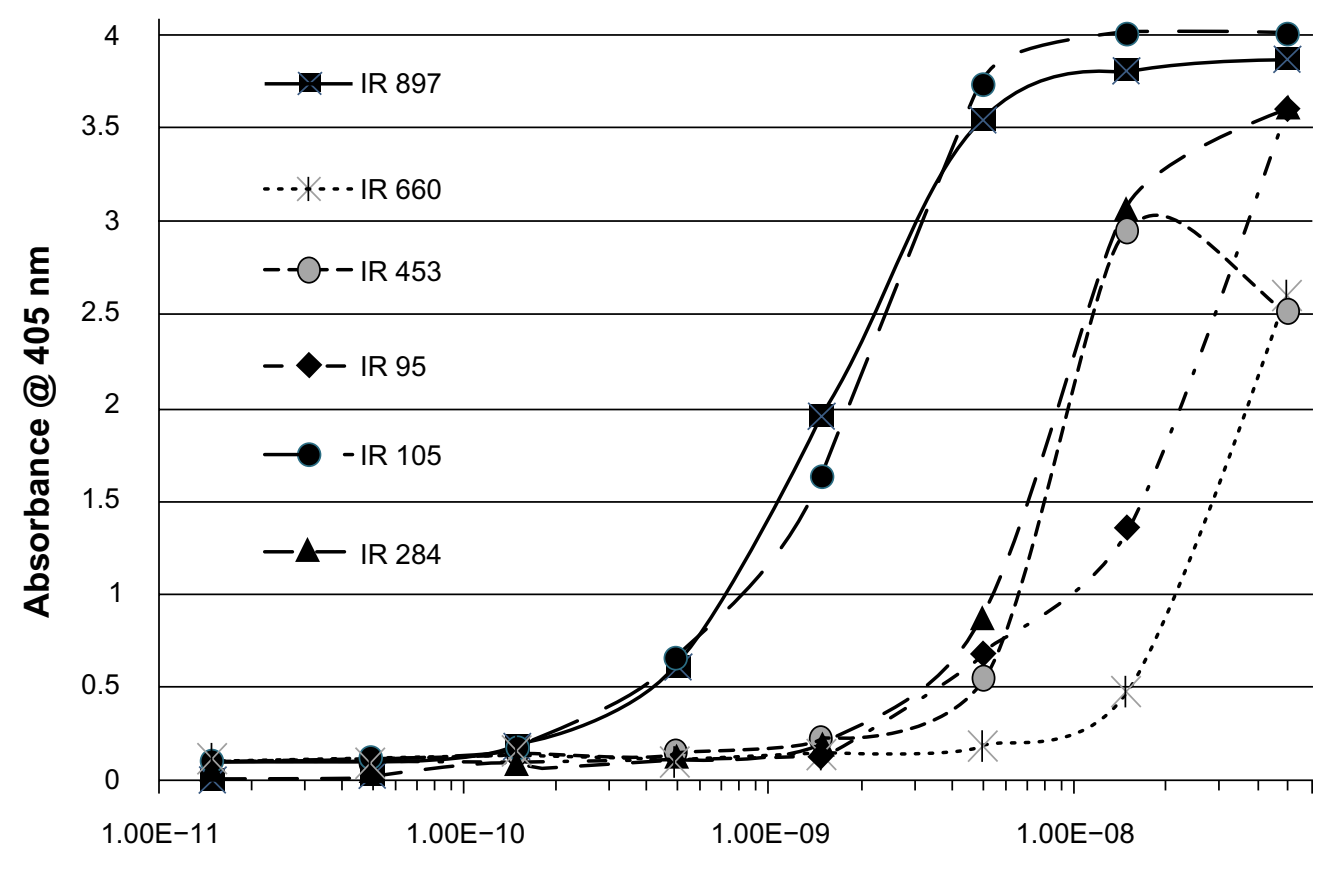

Concentration of insulin-HRP (M)

Figure 3 Some of the data from binding studies of insulin-HRP to peptides derived from the IR. These data, as well as additional experiments involving insulin-HRP binding to peptides derived from other receptors, were used to put together Table I. Binding constants were derived from the inflection points of the curves.

constants differ considerably depending on the technique used to measure them. Using HRP-labeled insulin binding to IR peptides immobilized to an ELISA plate yields binding constants in the low nanomolar range. Using UV spectroscopy to measure insulin binding to IR peptides free in solution yields binding constants about 200 to 1000 times lower (low-micromolar range). The difference in binding constants is not surprising in light of basic thermodynamics. Immobilizing a protein or peptide to a surface (whether in a cell membrane or on an ELISA plate) eliminates several degrees of freedom, significantly improving the probability of binding. In a similar study, Huppa, et $\mathrm{al}^{17}$ have shown that $\mathrm{T}$ cell receptor peptides binding to major histocompatibility (MHC) proteins also have about 100 to 1000 times lower affinity when both are in solution than when the MHC protein is immobilized on a surface. Both our data and the Huppa et al data suggest that it is therefore very important to consider the nature of the technique used to determine binding constants between molecules before interpreting their physiological significance. Solution-derived binding constants may indicate surface-bound binding constants that are significantly lower. The data must also be placed in the context of the physiological situation. In this instance, the IR is immobilized within the cell membrane and is better mimicked by the insulin-HRP ELSA experiments than by binding between free peptides in solution. Indeed, this thermodynamic argument is also of importance in understanding the selection pressures that governed the evolution of peptide receptors: the evolution of specific, immobilized receptors on cell surfaces would have increased binding (and thus information transfer) through cell surfaces by the same order (100- to 1000-fold) - a huge selection advantage over solution interactions or random tunneling through lipid membranes.

Significantly, our IR-derived peptide data are consistent with previous studies of insulin binding to the IR. Regions thought to be involved in insulin binding (Table 1) include its N-terminus (SwissProt numbers) 34-84;20 107-112;21,22 $238-393,22,23$ and more specifically; $264-272,{ }^{21}$ and $344-352,21$ $496-619 ; 24677-785^{25,26}$ and more specifically $728-737 ; ;^{20,21}$ and $792-797 .{ }^{24}$ Additionally, known mutations to the insulin receptor (summarized on the SwissProt website [http://www. expasy.ch] for human insulin receptor P06213) show that the 232-387, 496-619, and 677-797 as well as two additional regions, 113-119 and 925-937, are associated with loss of insulin binding resulting in leprechaunism, a genetic disease accompanied by severe insulin resistance. Longo et $\mathrm{al}^{27}$ and Whittaker et $\mathrm{al}^{20}$ for example, demonstrated that the Arg 86 
Table 2 Annotated sequence of the extracellular (amino acids I-956) portion of the insulin receptor (IR)

$\begin{array}{lrrrrr}10 & 20 & 30 & 40 & 50 & 60\end{array}$

MGTGGRRGAA AAPLLVAVAA LLLGAAGHLY PGEVCPGMDI RNNLTRLHEL ENCS VIEGHI

$\begin{array}{rrrrrr}70 & 80 & 90 & 100 & 110 & 120\end{array}$

QLLMFKTRP EDFRDLSFPK LIMITDYLL FRVYGLESLK DLFPNLTVR GSR FFFNYAL

$\begin{array}{rrrrrr}130 & 140 & 150 & 160 & 170 & 180\end{array}$

VIFEMVHLKE LGLYNLMNIT RGSVRIEKNN_ELCYLATIDW SRILDSVEDN YIUNKDDNE

$\begin{array}{lllll}190 & 200 & 210 & 220 & 230\end{array}$

ECGDICPGTA KGKTNCPATV INGQFVERCW THSHCQKVCP TICKSHGCTA EGLCCHSECL

$\begin{array}{lllll}250 & 260 & 270 & 280 & 290\end{array}$

GNCSQPDDPT KGVAGRNFYLDGRGVETCPP PYYHFQDWRG VNF SFCQDLH HKCKNSRRQG

$\begin{array}{lllll}310 & 320 & 330 & 340 & 350\end{array}$

GHAWIHANNK CIPECPSGYT MNSSNLLCTP CLGPCPKVCH LLEGEKTIDS VTSAQELRGC

$\begin{array}{llllll}370 & 380 & 390 & 400 & 410 & 420\end{array}$

TVINGSLIIN IRGGNNLAAE LEANLGLIEE ISG YLKIRRS YAL VSLSFFR KLRLIRGETL

$\begin{array}{llllll}430 & 440 & 450 & 460 & 470 & 480\end{array}$

EIGNYSFYAL DNQNLRQLHD WSKHNLTHQ-GKLFFHYNPK-LLSEIHKME EVSGTKGRQE

$\begin{array}{llllll}490 & 500 & 510 & 520 & 530 & 540\end{array}$

RNDIALKTNG DQASCENELL KFSYIRTSFD KHLRWEPYW PPDFRDLLGF MLFYKEAPYQ

$\begin{array}{llllll}550 & 560 & 570 & 580 & 590 & 600\end{array}$

NVTEFDGQDA CGSNSWTWVD IDPPLRSNDP KSQNHPGWLM RGLKPWTQYA IFVKTLVTFS

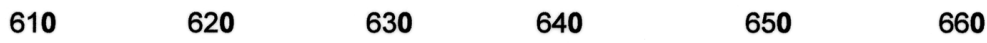

DERRTYGAKS DIIYVQTDAT NPSVPLDPIS VSNSSSQIIL KWKPPSDPNG NITHYLVFWE

$\begin{array}{llllll}670 & 680 & 690 & 700 & 710 & 720\end{array}$

RQAEDSELFE LDYCLKGLKL PSRTWSPPFE SEDSQKHNQS EYEDSAGECC SCPKTDSQIL

$\begin{array}{llllll}730 & 740 & 750 & 760 & 770 & 780\end{array}$

KELEESSFRK TFEDYLHNVAFVPRKTSSGT GAEDPRP//SRK RRSLGDVGNV TVAVPTVAAF

$\begin{array}{llllll}790 & 800 & 810 & 820 & 830 & 840\end{array}$

PNTSSTSVPT SPEEHRPFEK VVNKESLVIS GLRHFTGYRIELQACNQDTP EERCSVAAYV

$\begin{array}{llllll}850 & 860 & 870 & 880 & 890 & 900\end{array}$

SARTMPEAKA DDIVGPVTHE IFENNVVHLM WQEPKEPNGL IVLYEVSYRR YGDEELHLCV

$910 \quad 920 \quad 930 \quad 940 \quad 950$

SRKHFALERG CRLRGLSPGN YSVRIRATSL AGNGSWTEPT YFYVTDYLDV PSNIA

Notes: Bold letters represent insulin-like modules identified in Root-Bernstein., ${ }^{1,2}$ Bold italicized letters represent glucagon-like modules identified in Root-Bernstein.,2 Underlined regions represent insulin binding regions identified using blocking antibodies. ${ }^{22-24}$ Strike through regions represent insulin binding regions identified by photocrosslinking studies. ${ }^{16,20,25,26}$ Amino acids highlighted in gray blocks have been identified by alanine-scanning mutagenesis to be involved in insulin binding. ${ }^{16,20}$ Amino acids in large font are mutations associated with various forms of Leprechaunism, in which there is decreased or obliterated insulin binding to the IR (derived from annotations in SwissProt ID\# P062I3). The two Cys in black boxes covalently link the alpha chain of the IR (28-758) to the beta chain (759 ff.). This disulfide bond links to insulin-like modules, mimicking the structure of insulin itself. The double lines after amino acid 758 denote the place at which the IR is cleaved into alpha and beta chains. As can be seen by inspection of this Table, all of insulin-like modules correspond to regions of the IR identified by at least one, and in some cases as many as four different methods, as being important to insulin binding. We suggest that the insulin-like module spanning 897-916, which has been very little studied by previous investigators, may be far more important to insulin binding than has previously been thought. Glucagon-like modules are significantly less associated with identified regions or insulin binding. The Table also illustrates the fact that some regions of the IR that are essential to insulin binding do not correspond to insulin-like modules, so modular evolution does not explain all aspects of the IR structure.

(SwissProt, 113 - Table 1) is critical to activation of glucose transport. The same residue when mutated to Pro results in complete abolition of insulin binding (see SwissProt annotations for P06213). Ala scanning mutagenesis (reviewed in De Meyts and Whittaker $)^{16}$ has also identified the five amino acids following this Arg 86 (SwissProt numbering, 113) as being essential to insulin binding. This sequence of amino acids sits right in the center of one of the insulin-like modules of the IR. Similarly, the insulin-like sequence at 222-250 has been shown to be involved in insulin binding through antibody studies, ${ }^{22,23}$ affinity photolabeling, ${ }^{16}$ and mutation (SwissProt P06213). In fact, all of the insulinlike modules (but none of the glucagon-like modules) listed in Table 1 are within one of the regions defined by 
previous investigators as being associated with high affinity insulin binding, with one major exception, and that is the 897-916 region that we have identified as having both excellent insulin-binding and glucose-binding capacity. Given that this region is on the extracellular portion of the beta chain of the IR (Table 2), and is involved through a disulfide bond to the alpha chain of the IR (Table 2), it is in a perfect region to act as a highly sensitive "switch" modulating transmembrane information flow. As far as we can tell, no research has been performed on this region by those investigating insulin binding to the IR, since the focus has been almost exclusively on the alpha chain. We predict that the extracellular region of the beta chain will turn out to be critical for the binding of insulin and the transduction of its message intracellularly.

The data concerning glucose binding to insulin-like modules of the IR is also consistent with other research on the nature of glucose-binding sites. Our experiments reveal binding of glucose to insulin with a high affinity binding of $250 \mu \mathrm{M}$ and a low affinity of $30 \mathrm{mM}$, which are consistent with the binding constants reported previously by Anzenbacher and Kalous. ${ }^{10,11}$ Similarly, insulin-like peptides in the IR that have binding constants in the range of 3 to $30 \mathrm{mM}$. These binding constants are physiologically relevant since normal blood glucose levels in human beings fluctuate around $5 \mathrm{mM}$, and under hyperglycemic conditions associated with diabetes can range up to $50 \mathrm{mM} \cdot{ }^{28}$ We have demonstrated elsewhere ${ }^{14}$ that varying the concentration of glucose from $1 \mathrm{mM}$ to $25 \mathrm{mM}$ has very significant effects on insulin binding to its receptor, though to what extent the differences in binding are due to glucose binding to insulin, glucose binding to the IR, or both, could not be determined definitively. Our data were consistent with experiments by other investigators showing that glucose concentration affects insulin activity in a variety of assays (reviewed in ${ }^{16}$ ).

The IR sequences that we have observed to bind glucose are also consistent with what is known about glucose binding protein sequences more generally. Li et $\mathrm{al}^{29}$ analyzed a number of different glucose-binding proteins and concluded that "a possible glucose binding site can be made by placing Asp and Asn around glucose for hydrogen bonding and Phe on both sides of glucose for hydrophobic interaction." Notably, each of the four peptides listed in Table 1 that bind glucose most tightly have a variation of the $\mathrm{Li}$ et al motif, especially if one is willing to consider reasonable substitutions, such as Leu or Tyr for Phe. The glucose binding regions of the IR include 100-106: LeuLysAspLeuProAsn;
113-118: ArgLeuPhePheAsnTyr; 239-246: LeuGly $\underline{\text { AsnCys- }}$

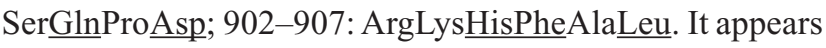
that Arg and Lys may also play a role in glucose binding in these peptides, perhaps forming hydrogen or ionic bonds. Notably, three of these sequences are cognates of a single previously identified glucose binding site on the B chain of insulin, in which Glu substitutes for Asp in the binding motif: LeuValGluAlaLeuTyrLeuValCysGlyGluArgGlyPhe (underlined in Table 1). ${ }^{12,13}$ Our data are therefore consistent with other studies of glucose binding to proteins. We have argued previously that the IR may therefore represent a glucose sensor, and have demonstrated experimentally that insulin binding to the IR is certainly glucose concentrationsensitive. ${ }^{14}$ The existence of glucose binding sites on the IR therefore links IR structure and function in a manner that is consistent with the hypothesis that evolution of receptor structure-function was governed by selection for molecularly complementary modules.

Notably, this evolutionary theory of IR structure and function has a number of potential clinical implications. It is also well-documented that people who develop type 1 (insulin-dependent) diabetes are characterized by having antibody and Tcells against insulin epitopes. ${ }^{30-38}$ We predict from the data presented here that the insulin-like modules of the IR will also be targets of these anti-insulin antibodies, resulting in both insulin resistance and also malfunction of the glucose-sensor function of the IR. Since many people with diabetes also develop anti-glucagon antibodies, ${ }^{39,40}$ it is possible that IR function can also be compromised by anti-glucagon antibodies in diabetes that cross-react with glucagon-like modules of the IR. As far as we know, no one has yet investigated any of the possibilities raised by this evolutionary approach to understanding IR structure and function.

In sum, the data presented here demonstrate that insulinlike modules almost certainly play functional roles in insulin binding in the modern human IR. This conclusion is supported by evidence that both the insulin-like and glucagon-like modules are very highly conserved in the IR throughout evolution from insects through human beings, ${ }^{2}$ suggesting that these modules are critical components of IR function. Thus, the evidence supports the hypothesis that the IR evolved from an insulin-like molecule, possibly insulin itself. Whether glucagon-like modules are also essential components of the IR, perhaps either structurally, or as low-affinity binding sites, remains conjectural. Perhaps these glucagon-like modules are actually glucagon binding sites that allosterically modulate the IR. Further tests 
will be required to investigate these possibilities. In any event, we conclude that homocomplementary (insulin-like modules of the IR binding insulin) and heterocomplementarity (insulin and insulin-like modules of the IR binding glucose) likely played critical roles in the evolution of the IR by linking structure and function.

The hypothesis that homocomplementarity and heterocomplementarity play critical selective roles in the evolution of receptors and transporters is generally testable. For example, we have demonstrated by similarity searching that the glucose transporter also contains insulin-like modules localized specifically to its transport core. ${ }^{41}$ These insulin-like regions can be predicted to bind glucose at physiological concentrations, just as do the insulin-like modules of the IR characterized here. In addition, the glucagon receptor, like the IR, contains both glucagon-like and insulin-like sequences in regions associated with glucagon binding. ${ }^{1,2}$ The same type of study performed here can be carried out as a test of the complementarity hypothesis for glucagon-glucagon receptor co-evolution. And yet another aspect of that hypothesis would suggest that just as insulin binds directly to glucose, glucagon might interact with some other component of the glucose regulation as well. Since insulin mediates glucose transport into cells, while glucagon mediates conversion of glycogen into glucose for release from the liver, one possible conjecture would be that glucagon will bind to glycogen and perhaps even act on it as a very weak enzyme to convert it to glucose. In this manner, molecular complementarity would integrate a wide range of structure-function relationships in the evolution of the glucose regulation system. These chemical interactions would then have become the basis for the evolution of the more complex regulatory systems that now govern cell function. If so, each of these elements should bear the stamp of the same kind of "molecular paleontology" revealed here.

\section{Disclosure}

The authors report no conflicts of interest in this work

\section{References}

1. Root-Bernstein RS. Molecular complementarity III. peptide complementarity as a basis for peptide receptor evolution: a bioinformatic case study of insulin, glucagon and gastrin. J Theor Biol. 2002;218(1):71-84.

2. Root-Bernstein RS. Peptide self-aggregation and peptide complementarity as bases for the evolution of peptide receptors: a review. $J \mathrm{Mol}$ Recognit. 2005;18(1):40-49.

3. Dwyer DS. Amino acid sequence homology between ligands and their receptors: potential identification of binding sites. Life Sci. 1989; 45:421-429.
4. Dwyer DS. Assembly of exons from unitary transposable genetic elements: implications for the evolution of protein-protein interactions. J Theor Biol.1998;194:11-27.

5. Schwabe C. New thoughts on the evolution of hormone-receptor systems. Comp Biochem Physiol A. 1990;97:101-106.

6. Peterson A, Seed B. Monoclonal antibody and ligand binding sites of the T cell erythrocyte receptor (CD2). Nature. 1987;329:842-846.

7. Root-Bernstein RS, Dobblestein C. Insulin binds to glucagon forming a complex that is hyper-antigenic and inducing complementary antibodies having an idiotype-antiidiotype relationship. Autoimmunity. 2001;33(3):153-169.

8. Dillon PF, Root-Bernstein RS, Lieder CM. Molecular shielding of electric field complex dissociation. Biophysical J. 2006;90:1432-1438.

9. Root-Bernstein RS, Dillon PF. Molecular complementarity I. The complementarity theory of life and its origins. J Theor Biol. 1997; 188:447-479.

10. Anzenbacher P, Kalous V. Binding of D-glucose to insulin. Biochim Biophys Acta. 1975;386:603-607.

11. Kalous V, Anzenbacher P. On the mechanism of the insulin-glucose interactions. Acta Diabetologica Latina. 1979;16:169-174.

12. Yu B, Caspar DL. Structure of cubic insulin crystals in glucose solutions. Biophys J. 1998;74:616-622.

13. Zoete V, Meuwly M, Karplus M. Investigation of glucose binding sites on insulin. Proteins. 2004;55(3):568-581.

14. Root-Bernstein RS, Vonck J. Glucose binds to the insulin receptor affecting the mutual affinity of insulin and its receptor. Cell Mol Life Sci. 2009;66:2721-2732.

15. Dillon PF, Root-Bernstein, RS, Lieder CM. Ascorbate enhancement of H1 histamine receptor coincides with ascorbate oxidation inhibition by histamine receptors. Am J Physiol Cell Physiol. 2006;291:C977-C984

16. De Meyts P, Whittaker J. Structural biology of insulin and IGF1 receptors: Implications for drug design. Nature Reviews Drug Discovery. 2002;1:769-783.

17. Huppa JB, Axmann M, Mortelmaier MA, et al. TCR-peptide-MHC interactions in situ show accelerated kinetics and increased affinity. Nature. 2010;463:963-967.

18. Pedersen O, Hjøllund E, Beck-Nielsen H, Lindskov HO, Sonne O, Gliemann J. Insulin receptor binding and receptor-mediated insulin degradation in human adipocytes. Diabetologia. 1981;20(6):636-641.

19. Martinnen A. Insulin degradation by intact erythrocytes is associated with low-affinity insulin binding sites. J Endocrinol Invest. 1989;12(7): 455-459.

20. Whittaker J, Sørensen H, Gadsbøll VL, Hinrichsen J. Comparison of the functional insulin binding epitopes of the $\mathrm{A}$ and $\mathrm{B}$ isoforms of the insulin receptor. JBC. 2002;277:47380-47384.

21. Ottensmeyer FP, Beniac DR, Luo RZT, Yip CC. Mechanisms of transmembrane signaling: Insulin binding and the insulin receptor. Biochemistry. 2000;39(40):12103-12112.

22. Yip CC, Grunfeld C, Goldfine ID. Identification and characterization of the ligand-binding domain of insulin receptor by the use of an antipeptide antiserum against amino acid sequence 241-251 of the alpha subunit. Biochemistry. 1991;30:695-701.

23. Yip CC. The insulin-binding domain of insulin receptor is encoded by exon 2 and 3. J Cell Biochem. 1992;48:19-25.

24. Prigent SA, Stanley KK, Siddle K. Identification of epitopes on the human insulin receptor reacting with rabbit polyclonal sera and mouse monoclonal antibodies. J Biol Chem. 1990;265:9970-9977.

25. Fabry M, Schaefer E, Ellis L, Kojro E, Fahrenholz F, Brandenburg D. Detection of a new hormone contact site within the insulin receptor ectodomain by the use of a novel photoreactive insulin. $J$ Biol Chem. 1992;267:8950-8956.

26. Huang K, Chan SJ, Hua QX, et al. The A-chain of insulin contacts the insert domain of the insulin receptor photo-cross-linking and mutagenesis of a diabetes-related crevice. JBC. 2007;282:35337-35349.

27. Longo N, Langley MD, Still SJ. Role of arginine 86 of the insulin receptor in insulin binding and activation of glucose transport. Biochim Biophys Acta. 1998;1402:86-94. 
28. Ganong WE. Review of Medical Physiology. 23rd Ed. New York: Prentice Hall; 2005.

29. Li T, Lee HB, Park K. Comparative stereochemical analysis of glucosebinding proteins for rational design of glucose-specific agents. $J$ Biomater Sci Polym Ed. 1998;9(4):327-344.

30. Griffin A, Zhao CW, Wegmann KW, Hickley WF. Experimental autoimmune insulitis. Induction by $\mathrm{T}$ lymphocytes specific for a peptide of proinsulin. Am J Pathol. 1995;147(3):845-857.

31. Schloot NC, Willemen S, Duinkerken G, de Vries RR, Roep BO. Cloned $\mathrm{T}$ cells from a recent onset IDDM patient reactive with insulin B-chain. J Autoimmun. 1998;11(2):169-175.

32. Narendran P, Williams AJ, Elsegood K, Leech NJ, Dayan CM. Humoral and cellular immune responses to proinsulin in adults with newly diagnosed type 1 diabetes. Diabetes Metab Res Rev. 2003;19(1):52-59.

33. Kent SC, Chen Y, Bregoll L, et al. Expanded T cells from pancreatic lymph nodes of type 1 diabetic subjects recognize an insulin epitope. Nature. 2005;435:224-228.

34. Nakayama M, Abiru N, Moriyama H, et al. Prime role for an insulin epitope in the development of type 1 diabetes in NOD mice. Nature. 2005; 435(7039):220-223.

35. Nakayama M, Beilke JN, Jasinski JM, et al. Priming and effector dependence on insulin B: 9-23 peptide in NOD islet autoimmunity. J Clin Invest. 2007;117(7):1835-1843.
36. Pinkse GG, Tysma OH, Bergen CA, et al. Autoreactive CD8 T cells associated with beta cell destruction in type 1 diabetes. Proc Natl Acad Sci U S A. 2005;102(51):18425-18430.

37. Pinkse GG, Boitard C, Tree TI, Peakman M, Roep BO. HLA class I epitope discovery in type 1 diabetes: independent and reproducible identification of proinsulin epitopes of CD8 T cells - report of the IDS T Cell Workshop Committee. Ann NY Acad Sci. 2006;1079:19-23.

38. Jarchum I, Baker JC, Yamada T, Takaki T, Marron MP, Serreze DV, DiLorenzo TP. In vivo cytotoxicity of insulin-specific CD8+ T-cells in HLA-A*0201 transgenic NOD mice. Diabetes. 2007;56(10): 2551-2560.

39. Gergely A, Korányl L, Halmos T, et al. Anti-glucagon antibodies in diabetes mellitus. Ann Immunol Hung. 1973;17:231-233.

40. Schopfer K, Matter L, Tenschert R, Bauer S, Zuppinger K. Anti-glucagon-cell and anti-adrenal-medullary-cell antibodies in islet-cell-autoantibody-positive diabetic children. N Engl J Med.1984; 310(23):1536-1537.

41. Root-Bernstein R. A modular insulin-like basis for the evolution of glucose transporters (GLUT) with implications for diabetes. Evolutionary Bioinformatics. 2007;2:317-331.
Journal of Receptor, Ligand and Channel Research

\section{Publish your work in this journal}

The Journal of Receptor, Ligand and Channel Research is an international, peer-reviewed, open access, online journal. The journal welcomes laboratory and clinical findings in the fields of biological receptors, ligands, channel and signal transduction research including: receptors and signalling; ligands; transporters, pores and channels; binding and activation; receptor

\section{Dovepress}

regulation; role of receptors in diseases and their treatment; molecular basis of membrane structure and functions; molecular models of membranes. The manuscript management system is completely online and includes a very quick and fair peer-review system. Visit http://www.dovepress.com/ testimonials.php to read real quotes from published authors. 